Grand Valley State University

ScholarWorks@GVSU

3-1999

\title{
Corporate Governance and Corporate Illegality: The effects of board structure on environmental violations
}

Marie A. McKendall

Grand Valley State University, mckendam@gvsu.edu

Carol M. Sanchez

Grand Valley State University, sanchezc@gvsu.edu

Paul Sicilian

Grand Valley State University, siciliap@gvsu.edu

Follow this and additional works at: https://scholarworks.gvsu.edu/mgt_articles

Part of the Strategic Management Policy Commons

\section{ScholarWorks Citation}

McKendall, Marie A.; Sanchez, Carol M.; and Sicilian, Paul, "Corporate Governance and Corporate Illegality: The effects of board structure on environmental violations" (1999). Peer Reviewed Articles. 19.

https://scholarworks.gvsu.edu/mgt_articles/19

This Article is brought to you for free and open access by the Management Department at ScholarWorks@GVSU. It has been accepted for inclusion in Peer Reviewed Articles by an authorized administrator of ScholarWorks@GVSU.

For more information, please contact scholarworks@gvsu.edu. 


\title{
CORPORATE GOVERNANCE AND CORPORATE ILLEGALITY: THE EFFECTS OF BOARD STRUCTURE ON ENVIRONMENTAL VIOLATIONS
}

\author{
Marie A. McKendall \\ Carol M. Sánchez \\ Paul Sicilian \\ Grand Valley State University \\ 220 Lake Huron Hall, Allendale, MI 49401 \\ (616) 895-3368 mckendam@gvsu.edu
}

\begin{abstract}
Introduction
Organizations can become socially dysfunctional in a number of ways. One type of macro dysfunction which is receiving popular and academic attention is corporate illegality. Corporate illegal behavior involves actions by an individual or a group within a business organization that violate an administrative, civil, or criminal law, and for which the organization is the primary intended beneficiary (Clinard \& Quinney, 1973: Schrager \& Short, 1978; Shover, 1978).

This paper contributes towards corporate illegality research by examining the relationship between corporate illegality and several previously untested dimensions of corporate board structure. Six hypotheses are posed to test the effects of outsider dominance, joint CEO-board chairpersons, stock ownership, social responsibility committees, and attorneys on boards on the incidence of corporate crime. The paper examines environmental violations rather than antitrust violations, which have been the focus of most previous research. We study administrative violations in addition to the criminal and civil infractions usually analyzed in corporate illegality research. The paper builds upon existing corporate crime research, and makes unique contributions by approaching it from these three previously underexplored points of view.
\end{abstract}

\section{Theories of Corporate Illegality}

Theories of corporate illegality generally concur that, in order for illegal behavior to occur, three factors must be present. First, there must be a motive or tension prompting the organization to engage in illegal behavior as a vehicle for achieving objectives and ensuring economic survival. Secondly, in the presence of this motivation, circumstances must exist which present the opportunity to break the law without detection and/or excessive penalty. Given motive and opportunity, whether or not corporate illegality will occur will depend on the presence of effective controls designed to prevent such behavior (McKendall \& Wagner, 1996; Baucus, 1994; Coleman, 1987; Finney \& Lesieur, 1982; Szwajkowski, 1986).

Scholars have proposed that two types of controls mitigate corporate illegal behavior. The first involves external constraints that provide incentives for corporate decision makers to abide by the law (McVisk, 1978; Yoder, 1978). Vigilant regulatory agencies 
and appropriate sanctions are examples of external controls. A second type of controls involves internal mechanisms which encourage legal compliance and/or penalize transgressions. Corporate culture and ethical practices, which establish behavioral norms and expectations, can function as internal control systems.

Another way to implement internal controls is to enhance the "watchdog" function of corporate boards of directors by requiring boards to be structured in certain ways (Nader, Green, \& Seligman, 1976; Eisenberg, 1977). The general argument is that certain board structures will increase the likelihood that a company meets its responsibilities not only to its stockholders but to all organizational stakeholders (Freeman, 1984). While Kesner, Victor, and Lamont (1986) found that adding outsiders to corporate boards did not lessen a firm's involvement in illegal activities, they suggested that research is needed to investigate what other types of boardroom reforms might reduce illegal activity of firms.

\section{Governance Structure}

The primary function of a Board of Directors is to oversee, monitor and evaluate the activities of a firm and its top management (Baysinger \& Butler, 1985; Kesner et al., 1986; Lorsch, 1989). Corporate governance theory has tended to examine the types of board structures and constraints that best enable a board to fulfill its mission of evaluation and control. This paper tests the proposition that board structure will be associated with a firm's tendency to engage in corporate illegal behavior. To date, only two empirical studies have examined such relationships. Kesner et al. (1986) studied 384 firms and found no relationship between the proportion of outside directors and civil antitrust violations. They also found no relationship between whether the CEO and Chair were the same person and civil antitrust violations. In a study of 100 firms, Gautschi and Jones (1987) found that various types of illegality increased as the proportion of outside directors increased. Conversely, illegal activity increased as the number of inside directors on the executive committee increased.

Outsider versus Insider Dominance: Outside side board members are defined as directors who are not current or retired managers of the organization they direct, nor of one of its subsidiaries (Kesner et al., 1986; Pfeffer, 1972). Reformists contend that if boards are dominated by outsiders, there will be a greater variety of knowledge and experience present (Bacon \& Brown, 1973; Firstenberg \& Malkiel, 1980; Kesner et al., 1986). It is argued that outside board members can serve organizational stakeholders better than insiders because they will more freely evaluate management's performance, and will more readily deter or remedy inappropriate situations. Thus, the greater independence of outside board members should allow them to see more clearly the potential long-term costs and disadvantages of illegal activity, and should enable them to resist management pressure to overlook such behavior (Kesner et al., 1986).

While there is no clear evidence that boards with a greater proportion of insiders are more likely to act illegally (Kesner et al., 1986), it has been found that boards with a greater proportion of insiders are more likely to incur shareholder lawsuits (Kesner \& Johnson, 1990). Further, a resource dependence perspective suggests that having a greater number 
of outsiders on the board when a critical decision must be made provides greater resources and information and helps to establish legitimacy (Pfeffer \& Salancik, 1978). Therefore, we argue that when faced with the motive and the opportunity to violate environmental law, a firm will be less likely to do so if there are more outsiders than insiders on the board. Outsiders will advocate a response that protects the legitimacy of the firm, and their greater voting power will defeat any alternative response. Based on these arguments, we pose the following hypothesis:

\section{H1: The greater the proportion of outside directors to inside directors on the board, the lesser the incidence of corporate illegality.}

Dual CEO-Chairperson Roles: There is close theoretical consensus that one individual should not jointly hold the roles of CEO and board chairperson (Mallette \& Fowler, 1992; Kesner et al., 1986). The fundamental argument is that a function of the chairperson is to evaluate the behavior of the CEO, and this is impossible to do if both jobs are held by the same person (Geneen, 1984). In short, a dual structure represents a conflict of interest. If a firm is faced with a strong motive and a compelling opportunity to violate the law, the lack of an objective monitoring presence may make the firm more likely to choose illegality. For example, the consequences of breaking an environmental law will be more difficult for the board chair to evaluate objectively if he/she is also the CEO. Without an independent monitor, the joint CEO-chairperson may decide that the benefits achieved by shirking an environmental law may exceed the costs of detection. Lorsch noted that "providing a leader [on the board] separate from the CEO could significantly help directors prevent crises, as well as to act swiftly when one occurs" (1989: 185). Based on these arguments, we hypothesize the following:

\section{H2: Firms with joint CEO-board chairpersons will have a greater incidence of corporate illegality than firms with separate CEOs and chairpersons.}

Stock Ownership by Officers and Directors: There is some speculation that the degree of financial involvement in the firm by officers and directors may compromise their ability to objectively evaluative and control firm choices (Kesner et al., 1986). Some scholars argue that this is not an issue because the directors of most companies do not hold a significant enough portion of their worth in company stock. They hold that the compensation received by most directors is not sufficient to align their interests with those of shareholders, and the stock component of most directors' compensation is rarely significant enough to make company performance an incentive for them (Monks \& Minow, 1995).

However, one survey revealed that twenty-four percent of companies made stock grants to their directors in addition to the cash portion of the compensation package (SpencerStuart \& Associates, 1991). It can be argued that including a stock grant of any size in the compensation packages of directors encourages directors to act more in the interests of shareholders and less in the interests of other stakeholders. Further, the more the personal fortunes of directors are dependent on the financial performance of the firm, 
the more important financial performance becomes relative to other competing outcomes. Directors who own significant portions of stock in the company may be more likely to ignore compliance with an environmental law if they perceive such an action will increase company profits and thereby their personal wealth. They may believe that it is more important to channel resources in ways that will directly contribute to shareholder returns, rather than invest them in costly equipment or processes that may be required for environmental compliance. Accordingly,

\section{H3: The greater the value of stock owned by officers and directors, the greater the incidence of corporate illegality.}

Board Committees: Some governance reform proposals argue that boards should enhance their control functions by forming committees that are responsible to particular constituents and to protecting the public interest. Board committees allow subgroups of directors to delve into details about specialized issues, such as environmental compliance, that the full board would not have time to consider (Lorsch, 1989). Special committees may include public policy, social responsibility, and the environment. These committees are designed to demonstrate that the board will be committed to legal and social responsibility and will balance the often conflicting interests of stakeholder groups. They send a message to stakeholders that the board wants to be a good corporate citizen (Monks \& Minow, 1995). Being good corporate citizens means complying with the law, particularly those laws that are directly related to the task of the committee. For example, it should be more difficult for a company to violate or ignore an environmental law when that company has a board committee whose task it is to specifically monitor the environmental behavior of the firm. Firms with social responsibility committees in place will be less likely to violate laws because the committee members will require more accountability from management to ensure that the firm is complying with environmental regulations. In addition, the presence of such committees should send a message to the organization that legal and socially responsible behavior is desired and valued. Based on these arguments, we hypothesize:

\section{H4: Firms with board-level public policy or social responsibility committees will have a lesser incidence of corporate illegality than firms without such committees.}

\section{Attorneys as Board Members}

One job of the board is to evaluate management's proposals. In complex situations, it may not be judicious to assume that management's staff of consultants, lawyers, and other advisors will always remain truly objective when evaluating such proposals (Bowen, 1994: 105). When a legal issue arises, management-retained lawyers may provide a limited point of view to the board. Boards that do not have legal expertise of their own may be reluctant to contradict that advice. Since litigation is a complex and frequent threat, a board should have advisors of its own who can evaluate and challenge the views of management counsel (Bowen, 1994). For example, when faced with the issue of how a firm should respond to an environmental law, boards with members who 
are attorneys will have the ability to draw from their own expert legal advice, independent of the advice that was used to develop recommendations made by management. The lawyer who is also a board member will be expected to raise questions and issues about the proposed action that may have been omitted by management's. A board of directors that has a lawyer as at least one of its members has readily available yet additional information and expertise that can help the board maintain its legitimacy (Pfeffer \& Salancik, 1978) and its independence from management when it dealing with issues that involve the threat of legal liability. We therefore hypothesize:

\section{H5: Firms with attorneys on their boards will have a lesser incidence of corporate illegality.}

Sample:

\section{Methodology}

The sample for this study consisted of the largest 150 U.S. industrial organizations, as identified by the 1988 edition of Ward's Business Directory. In order to identity these firms, we chose the largest public companies whose primary SIC code was in manufacturing. Environmental laws are generally aimed at curtailing pollution produced by manufacturing firms, and publicly-owned companies are required to disclose information about several of the variables in the study. In order to accurately track violation day, we also excluded from the population companies whose activities were too dispersed (i.e., less than fifty percent of the firm's business was conducted by the parent organization or a single subsidiary). We further excluded companies for which complete proxy statement data was not available.

\section{Dependent Variable:}

Environmental violations: Environmental laws are among those most frequently violated by U.S. firms (McKendall \& Wagner, 1996; Hill et al., 1992). Environmental regulation in the United States is largely under the jurisdiction of the Environmental Protection Agency (EPA), which administers federal environmental laws, sets standards, ensures compliance, and performs supportive research (Steiner \& Steiner, 1988). The EPA oversees legislation involving air quality, water quality, solid and toxic waste disposal, toxic chemicals, radiation, and noise pollution. The agency can initiate administrative, civil, or criminal proceedings against a company; the seven possible enforcement actions include warnings, recalls, agency and court orders, injunctions, monetary fines, and criminal prosecution of officers. Since commonly accepted definitions of corporate crime include any action punishable by administrative, civil, or criminal law (Clinard et al., 1979; Reiss \& Biderman, 1980; Yeager, 1986), we have included all three types of violations in this study.

We obtained information about enforcement actions against our sample companies between 1985 and 1987 from printouts produced by the EPA and 10K reports. From these two sources we identified 2,076 violations attributable to our sample of 150 firms. Of these violations, there were 1,157 notices/warnings of violation, which we designated as non-serious violations; there were 919 agency and court orders/verdicts, which we 
designated as serious. Descriptive statistics and partial correlations are presented in Tables $1 \mathrm{a}$ and $1 \mathrm{~b}$.

There is a dispute in the literature as to whether the absolute number of violations, or a proportionate measure relative to organization size should be used. Some researchers (Clinard et al., 1979; Hill et al., 1992) have argued that using an absolute measure of size is inappropriate since larger firms have more opportunities to commit violations and organization size will therefore be positively correlated with violations even if the hypothesized reasons for the correlation are unfounded. They contend that the correct question is whether larger firms commit proportionately more violations than smaller firms. To capture this, some studies have used the ratio of violations to a unit of organization size as the dependent variable and then included size as one of the independent variables. Using a proportionate measure, however, is equivalent to regressing the absolute number of violations on all independent variables interacted with size, thus including the square of size as an independent variable. Since we are interested in the direct effect of the stated dimensions of corporate board structure on corporate illegality, and have not hypothesized interaction effects between any of these variables and organization size, we used an absolute measure of violations and included both size and a quadratic term for size as independent variables.

Suppose we specify our model as: Violations $=\alpha+\beta_{1}$ Size $+\beta_{2} \operatorname{Size}^{2}+\beta_{3} X$, where $X$ is a vector of all independent variables other than size. The effect of an increase in corporation size, other things constant, is: $\beta_{1}+2 \beta_{2}$ Size. The way this effect changes with size, then, is: $2 \beta_{2}$. Thus, if $\beta_{1}+2 \beta_{2}$ Size $>0$, then violations increase with Size and if $\beta_{2}>0$, then violations increase with Size at an increasing rate.

Independent Variables:

Inside Directors: This was measured by calculating a ratio of the number of inside board members, divided by the total number of board members for 1983 and 1984; the two ratios were then averaged. All data for the independent variables was obtained from 1983 and 1984 proxy statements.

Joint CEO-Chairpersons. This was measured with a dummy variable, scored 1 if the CEO and the Chairperson were the same person during 1983 or 1984, and scored 0 if they were not.

Value of Stock Owned by Directors and Officers: This measure is the total number of shares reported by each company as beneficially owned by all officers and directors at the beginning of each year, multiplied by an average of the highest and the lowest stock price during that year. The values for 1983 and 1984 were then averaged.

Committees: This measure was created by using a dummy variable, scored 1 if a social responsibility, ethics, public affairs, or environmental committee existed on the board of directors during 1983 or 1984, and scored 0 if it did not. 
Attorneys: This was measured using a dummy variable, scored 1 if there was an attorney on the board of directors during 1983 or 1984, and scored 0 if there was not.

\section{Control Variables:}

Because previous research on motive and opportunity variables has often produced positive results, we entered the four most commonly supported variables into our model as controls.

Industry profitability: We measured industry profitability as the two year (1983-1984) average return on assets for the four-digit SIC industry code in which the firm did the largest share of its business, using data from Dun \& Bradstreet's Industry Norms and Key Business Ratios.

Firm profitability: This was calculated as a firm's average return on assets (ROA) and its industry's average ROA during the two fiscal year period of 1983-1984, using annual reports and Dun \& Bradstreet data.

Organization Size: Using data from annual reports and Moody's Industrial Reports, firm size was measured as the average number of employees for each firm during the 1983-1984 time period.

Industry Concentration: This measure was based on data published by the U.S. Bureau of the Census in 1982. The industry concentration measure employed the Herfindahl-Hirshman index, calculated by squaring and summing the market shares of the fifty largest firms in an industry.

\section{Industry Control:}

A few other studies have found that environmental violations tend to occur in some industries more than others; it is logical to assume this is because some manufacturing processes are more polluting than others. For instance, the paper, chemical, petroleum, and primary metals industries have been found to be high violators (McKendall \& Wagner, 1996). To account for possible industry effects, we created a dummy variable equal to 1 for any firm with a primary SIC code of $26,28,29$, or 33 . When this dummy variable was included in our regressions, the coefficients were statistically insignificant and no other estimated coefficients were significantly altered. Therefore, we report the regression results without the industry controls included.

\section{Procedure:}

Because 37 of our sample firms had no serious violations and 28 had no non-serious violations, we used Tobit analysis to estimate the effects of board structure on violations. We entered firm size, industry concentration, industry profitability and firm profitability as control variables. The regression results are presented in Table 2 .

\section{Results}


The results of the TOBIT regression analyses demonstrated that only one variable, the value of stock owned by corporate officers and directors, was positively and significantly associated with corporate illegality, and then only for serious violations. As hypothesized, the greater the value of stock owned by officers and directors, the greater the number of violations committed. All of the other hypotheses -- joint CEO/chair, ethics committee, and attorney on the board, were insignificant for all serious and non-serious violations.

\section{Discussion and Conclusions}

These findings suggest several things. First, our research, like that of Kesner et al. (1986) and Gautschi \& Jones (1987), fails to support several of the most popular board reform propositions. All three studies refute the contention that boards dominated by outsiders will improve social performance and result in fewer legal violations. Reformers should perhaps consider additional vehicles to ensure corporate social performance.

Secondly, we found that the presence of an ethics committee on the board had no significant effect on illegal actions. This concurs with other studies which show various corporate ethical practices (i.e., codes, committees, training) to be unrelated to illegality (McKendall, 1990; Mathews, 1987). It may be that such board committees, which often meet only a few times a year, are seen as mere window dressing, and not as a meaningful organizational force.

Finally, the significant relationship between the value of stock ownership and illegal acts suggests that the degree of director's and officers' financial involvement in the firm may indeed have a compromising effect on the tendency of these people to carry out their oversight function (Kesner et al., 1986). Board members and officers who own a greater dollar amount of stock may be more likely to overlook the consequences of committing a serious environmental violation, because they may feel that complying with the law will cost too much. The high cost of compliance will affect profits, and drive the price of stock downward. This would have a negative effect on personal wealth, and therefore should be avoided. Board members and officers who have greater stock interest in their companies may define the best interests of their firm in terms of short-run, financial performance indicators rather than more comprehensive outcomes.

Our study does not support the contention that structuring a board in a certain way will act to prevent illegal activities. It does, however, suggest that the personal circumstances of directors and officers, whomever they might be, are an influence on illegality. Daboub, Rasheed, Priem, \& Gray (1995) recently advanced a theory that the characteristics of top management might have an impact on corporate illegal activity. Our finding lends tentative support to this hypothesis. Certainly, it invites further research in an area which has received little empirical scrutiny. 
Table 1a: Means and Standard

Deviations

\begin{tabular}{lcc}
\hline & Mean & Standard Deviations \\
\cline { 1 - 3 } Non-serious violations & 7.71 & 10.41 \\
Serious violations & 6.127 & 8.354 \\
CEO/Chair & 0.827 & 0.38 \\
Ethics Committee & 0.22 & 0.42 \\
Lawyer & 0.53 & 0.50 \\
\% Inside Directors & 33.77 & 12.28 \\
Industry Concentration & 790.69 & 660.36 \\
Size (number of employees) & 460.71 & 664.28 \\
Industry Profits & 6.80 & 4.95 \\
Firm Profits & 6.19 & 5.06 \\
Value of Stock & 139.27 & 359.71 \\
\hline
\end{tabular}

Table 1b:

Partial

\section{Correlation}

$\mathbf{s}$

\begin{tabular}{|c|c|c|c|c|c|c|c|c|c|}
\hline & $\begin{array}{l}\text { \% Inside } \\
\text { Directors }\end{array}$ & CEO/Chair & $\begin{array}{l}\text { Value of } \\
\text { Stock }\end{array}$ & $\begin{array}{c}\text { Ethics } \\
\text { Committee }\end{array}$ & Lawyer & $\begin{array}{l}\text { Industry } \\
\text { Profit }\end{array}$ & $\begin{array}{c}\text { Firm } \\
\text { Profits }\end{array}$ & Size & $\begin{array}{c}\text { Industry } \\
\text { Concentration }\end{array}$ \\
\hline $\begin{array}{l}\% \text { Inside } \\
\text { Directors }\end{array}$ & 1 & & & & & & & & \\
\hline CEO/Chair & -.130 & 1 & & & & & & & \\
\hline Value of Stock & .168 & -.086 & 1 & & & & & & \\
\hline Ethics Committee & -.022 & .0306 & -.050 & 1 & & & & & \\
\hline Lawyer & .082 & -.005 & .095 & .013 & 1 & & & & \\
\hline Industry Profits & .073 & -.043 & .027 & .014 & -.111 & 1 & & & \\
\hline Firm Profits & .053 & -.135 & .154 & .036 & .054 & .298 & 1 & & \\
\hline Size & -.001 & .047 & .113 & .276 & -.029 & -.053 & .077 & 1 & \\
\hline $\begin{array}{l}\text { Industry } \\
\text { Concentration }\end{array}$ & .042 & -.041 & -.047 & .138 & .041 & -.139 & .122 & .280 & 1 \\
\hline
\end{tabular}




\begin{tabular}{|c|c|c|}
\hline & Non-Serious & Serious \\
\hline$\%$ Inside Directors & $\begin{array}{l}.1028 \\
(1.40)\end{array}$ & $\begin{array}{l}.0448 \\
(0.83)\end{array}$ \\
\hline CEO/Chair & $\begin{array}{l}.2977 \\
(0.12)\end{array}$ & $\begin{array}{l}.2214 \\
(0.12)\end{array}$ \\
\hline $\begin{array}{l}\text { Stock Value Held by Officers and } \\
\text { Directors }\end{array}$ & $\begin{array}{c}4.79 \mathrm{e} 09 \\
(1.76)^{*}\end{array}$ & $\begin{array}{l}4.08 \mathrm{e} 09 \\
(2.04)^{* *}\end{array}$ \\
\hline Ethics Committee & $\begin{array}{l}.7701 \\
(0.33)\end{array}$ & $\begin{array}{l}1.2003 \\
(0.69)\end{array}$ \\
\hline Lawyer & $\begin{array}{c}2.6366 \\
(1.36)\end{array}$ & $\begin{array}{l}.4001 \\
(0.28)\end{array}$ \\
\hline Industry Profits & $\begin{array}{c}.5714 \\
(2.79)^{* * *}\end{array}$ & $\begin{array}{l}.3883 \\
(2.57)^{* *}\end{array}$ \\
\hline Firm Profits & $\begin{array}{c}.3438 \\
(1.66)^{*}\end{array}$ & $\begin{array}{l}-.4409 \\
(2.98)^{* * *}\end{array}$ \\
\hline Size & $\begin{array}{c}.0001 \\
(4.61)^{* * *}\end{array}$ & $\begin{array}{l}.0001 \\
(5.03)^{* * *}\end{array}$ \\
\hline Size Squared & $\begin{array}{c}1.69 \mathrm{e} 10 \\
(2.99) * * *\end{array}$ & $\begin{array}{l}1.06 \mathrm{e} 10 \\
(2.56)^{* *}\end{array}$ \\
\hline Industry Concentration & $\begin{array}{l}.0022 \\
(1.41)\end{array}$ & $\begin{array}{l}.00278 \\
(2.40)^{* *}\end{array}$ \\
\hline Constant & $\begin{array}{c}11.8578 \\
(2.85)^{* * *}\end{array}$ & $\begin{array}{l}8.0308 \\
(2.60)^{* * *}\end{array}$ \\
\hline Pseudo $\mathrm{R}^{2}$ & .050 & .072 \\
\hline $\begin{array}{c}\text { Notes: "t"-statistics in parentheses } \\
{ }^{*} \mathrm{p} \text {-value } \leq .10 \\
* * \mathrm{p} \text {-value } \leq .05 \\
\text { *** p-value } \leq .01\end{array}$ & & \\
\hline
\end{tabular}

